\title{
Antiplasmodial, anti-trypanosomal, anti-leishmanial and cytotoxicity activity of selected Tanzanian medicinal plants
}

\author{
H.M. MALEBO ${ }^{1,2,3}$, W. TANJA ${ }^{3}$, M. CAL ${ }^{3}$, S.A.M. SWALEH ${ }^{2}$, M.O. OMOLO ${ }^{4}$, A. HASSANALI ${ }^{5}$, U. \\ SÉQUIN $^{3}$, M. HAMBURGER ${ }^{3}$, R. BRUN ${ }^{1}$ and I.O. NDIEGE ${ }^{*}$ \\ ${ }^{1}$ National Institute for Medical Research, P.O. Box 9653, Dar es Salaam, Tanzania \\ ${ }^{2}$ Department of Chemistry, Kenyatta University, Nairobi, Kenya \\ ${ }^{3}$ University of Basel, Basel, Switzerland \\ ${ }^{4}$ Masinde Muliro University of Science \& Technology, Kakamega, Kenya \\ ${ }^{5}$ International Centre for Insect Physiology and Ecology, Nairobi, Kenya
}

\begin{abstract}
The antiplasmodial, anti-trypanosomal and anti-leishmanial activity of 25 plant extracts obtained from seven Tanzanian medicinal plants: Annickia (Enantia) kummeriae (Annonaceae), Artemisia annua (Asteraceae), Pseudospondias microcarpa (Anacardiaceae), Drypetes natalensis (Euphorbiaceae), Acridocarpus chloropterus (Malpighiaceae), Maytenus senegalensis (Celastraceae) and Neurautanenia mitis (Papilonaceae), were evaluated in vitro against Plasmodium falciparum K1, Trypanosoma brucei rhodesiense STIB 900 and axenic Leishmania donovani MHOM-ET-67/82. Out of the 25 extracts tested, 17 showed good antiplasmodial activity $\left(\mathrm{IC}_{50} 0.04-5.0 \mu \mathrm{g} / \mathrm{ml}\right), 7$ exhibited moderate anti-trypanosomal activity $\left(\mathrm{IC}_{50} 2.3-2.8 \mu \mathrm{g} / \mathrm{ml}\right)$, while 5 displayed mild anti-leishmanial activity $\left(\mathrm{IC}_{50} 8.8-9.79 \mu \mathrm{g} / \mathrm{ml}\right)$. A. kummeriae, A. annua, P. microcarpa, D. natalensis, M. senegalensis and N. mitis extracts had good antiplasmodial activity $\left(\mathrm{IC}_{50} 0.04-2.1 \mu \mathrm{g} / \mathrm{ml}\right)$ and selectivity indices $(29.2-2,250$ $\mu \mathrm{g} / \mathrm{ml})$. The high antiplasmodial, moderate anti-trypanosomal and mild anti-leishmanial activity make these plants good candidates for bioassay-guided isolation of anti-protozoal compounds which could serve as new lead structures for drug development.
\end{abstract}

Keywords: Malaria, trypanosomiasis, leishmaniasis, medicinal plants, Tanzania

\section{Introduction}

Malaria, trypanosomiasis and leishmaniasis are among the most important public health problems in developing regions (WHO, 2002). Due to their prevalence, virulence and drug resistance status; they are the most serious and widespread parasitic diseases in the tropics (Bryceson,1996;Marsden,1996;Olliaro\&Cattani, 1996; WHO, 2002). In view of the complications in dealing with malaria, trypanosomiasis and leishmaniasis, chemotherapy remains a dependable cornerstone in the control of these diseases. In such efforts, plants are considered to be important sources for lead compounds owing to their successful use in the treatment of various ailments since antiquity (Sandberg \& Cronlund, 1977).

Several medicinal plants are traditionally used for the treatment of malaria and other protozoal infections in East, Central and West African countries (Akendengue \& Louis, 1994; Gessler et al, 1995; Dhawahan et al, 1997; Nkeh et al, 2001, 2003). In 1993, Artemisa annua was introduced in Tanzania and is now widely grown in the highlands where it has become a popular remedy for malaria in the form of herbal teas and infusions (Swiss Invest Forum, 2007). Although several phytochemical and pharmacological investigations have been done, $A$. апnиа was included to assess the efficacy of the local herbal extracts for the treatment of malaria and other protozoal diseases taking into consideration that, it is an exotic plant species growing in different soil and weather conditions. A. annua is reported to contain terpenes and flavonoids, but the endoperoxide sesquiterpene, artemisinin is the most pharmacologically useful compound reported to date.

Ethnomedical information reveals that several Annickia (formerly Enantia) species are widely used for the treatment of malaria and other ailments (Betti, 2002). For instance Enantia chlorantha is used for the treament of malaria in West Africa (Wafo et al., 1999). Enantia chlorantha exhibited in vivo activity against Plasmodium yoelii in experimentally infected mice (Agbaje \& Onabanjo, 1991). Similarly, E. polycarpa is used for the treatment of malaria in West Africa (Bouquet \& Debray, 1974). The stembark extract of E. polycarpa showed high in vitro antiplasmodial activity against $P$. falciparum $\mathrm{K} 1$ strain $\left(\mathrm{IC}_{50} 0.126 \mu \mathrm{g} / \mathrm{ml}\right)$ and high selectivity (SI 616) (Atindehou et al., 2004). The chemistry of $E$. chlorantha and E. polycarpa has been extensively

* Correspondence: Isaiah O. Ndiege; indiege@yahoo.com 
studied (Leboeuf \& Cave, 1972; Jössang et al., 1977a, b; Wafo et al., 1999). The stem-bark and the leaves of E. chlorantha and E. polycarpa contain many biologically active alkaloids that are closely related. Several quinoline and isoquinoline alkaloids, including quinine and dihydroquinidine, have been isolated from $E$. polycarpa (Buzas et al., 1959, 1965). This may explain the extensive use of E. polycarpa stembark as an anti-malarial remedy in West Africa.

Pseudospondias microcarpa and P. longifolia are used widely in African traditonal medicine (Gessler et al., 1995; Noumi \& Yomi 2001). Pseudospondias longifolia is used in Gabon for reducing heart palpitation whereas $P$. microcarpa is used in Tanzania and the Democratic Republic of Congo (DRC) for the treatment of malaria and in Cameroon for constipation (Gessler et al., 1995; Noumi \& Yomi 2001). Plants in the genus Drypetes are used in African traditional medicine for the treatment of various ailments (Akendengue \& Louis, 1994; Gessler et al., 1995; Nkeh et al., 2003). Drypetes gossweileri is used for the treatment of rheumatism and filariasis in Gabon (Akendengue \& Louis, 1994). Drypetes molunduana is used as a pain killer, antiinflammatory and anti-tumor drug in Cameroon (Nkeh et al., 2003). Drypetes natalensis is used for the treatment of malaria and other ailments in Tanzania (Gessler et al., 1995).

The tuber of Neorautanenia mitis is widely used as fish poison in most parts of Africa (Vongtau et al., 2000, 2004; Joseph et al, 2004). $N$. mitis contains pachyrrhizine, rotenone, 12hydroxyrotenone, neorotenone, neorautanone, neoduline, nepseudin, 4-methoxyneoduline, rautandiol $\mathrm{A}$ and rautandiol B. Several Maytenus species are widely used in Africa for the treatment of malaria and other ailments (Gessler et al., 1995). Maytenus senegalensis is commonly used for the treatment of malaria and bacterial infections in western Tanzania (Gessler et al., 1995). The chemistry and pharmacology of Maytenus senegalensis are well documented (Hussein et al, 1999; Abraham et al., 2006).

In our continuing efforts to validate the efficacy and safety of plants most frequently used in the treatment of malaria, we investigated the cytotoxicity and anti-protozoal activity of seven selected Tanzanian medicinal plants. We hereby report the antiplasmodial, anti-trypanosomal, anti-leishmanial and cytotoxicity activity of petroleum ether, dichloromethane and methanol extracts of Annickia (Enantia) kummeriae (Annonaceae), Artemisia annua (Asteraceae), Pseudospondias microcarpa (Anacardiaceae), Drypetes natalensis (Euphorbiaceae), Acridocarpus chloropterus (Malpighiaceae), Maytenus senegalensis (Celastraceae) and Neurautanenia mitis.

\section{Materials and Methods}

\section{Collection and processing of plant material}

The plants were collected in different parts of Tanzania in 2005 (Table 1). The leaves, seeds, root-bark and stem-bark were dried and powdered using pulveriser. The plant powders $(500 \mathrm{~g})$ were sequentially extracted with petroleum ether, dichloromethane and methanol. The extraction was done at room temperature for $48 \mathrm{~h}$ with intermittent shaking, the solvent extract decanted and filtered off. After filtration, the solvent was removed under reduced pressure and the extracts dried further under a stream of nitrogen for $24 \mathrm{~h}$ before being weighed and used for biological assays.

Table 1: List of plant species collected

\begin{tabular}{lll}
\hline Botanical name & Parts collected & Location of collection \\
\hline Annickia kummeriae & Leaves, stem and root bark & Amani, Tanga \\
Acridocarpus chloropterus & Leaves, stem and root bark & Pugu, Dar es Salaam \\
Pseudospondias microcarpa & Stem and root bark & Kashozi, Kagera \\
Drypetes natalensis & Stem and root bark & Buyango, Kagera \\
Maytenus senegalensis & Root bark & Kyamlaile, Kagera \\
Neurautanenia mitis & Tuber & Ifakara, Morogoro \\
Artemisia annua & Leaves and seeds & Njombe, Iringa \\
\hline
\end{tabular}




\section{In vitro assays}

Antiplasmodial activity was evaluated against the multi-drug resistant Plasmodium falciparum K1 strain (resistant to chloroquine and pyrimethamine), using the methods described by Matile \& Pink (1990). The parasites were maintained in a continuous in vitro culture and the quantitative assessment of in vitro antiplasmodial activity was determined by means of the microculture radioisotope technique. The inhibitory concentration $\left(\mathrm{IC}_{50}\right)$ represented the concentration that caused $50 \%$ inhibition in parasite growth, which was indicated by the uptake of the radio-labeled nucleic acid precursor, $\left[{ }^{3} \mathrm{H}\right]$-hypoxanthine, by $P$. falciparum K1 strain maintained on human red blood cells in vitro. The definition of the antiplasmodial activity used was: $\mathrm{IC}_{50}<0.5 \mu \mathrm{g} /$ $\mathrm{ml}$ - strong activity; $0.5-5.0 \mu \mathrm{g} / \mathrm{ml}$ - moderate activity; $5.0-10 \mu \mathrm{g} / \mathrm{ml}$ - mild activity and $\mathrm{IC}_{50}>10$ $\mu \mathrm{g} / \mathrm{ml}$ - inactive. Chloroquine and artemisinin $\left(\mathrm{IC}_{50} 0.063 \pm 0.03 \mu \mathrm{g} / \mathrm{ml}\right.$ and $0.002 \pm 0.0001 \mu \mathrm{g} / \mathrm{ml}$, respectively) were used as standards.

The in vitro antitrypanosomal activity was evaluated against Trypanosoma brucei rhodesiense STIB 900 strain, using the method of Räz et al. (1997). Minimum Essential medium (MEM) was supplemented according to Baltz et al. (1985) with 2-mercaptoethanol and $15 \%$ heat inactivated horse serum which was later added to each well on a 96-well microtiter plate. Drug dilutions together with $10^{4}$ bloodstream forms of T. b. rhodesiense STIB 900 in $50 \mathrm{ml}$ were added to each well and the plate incubated at $37^{\circ} \mathrm{C}$ under a $5 \% \mathrm{CO}_{2}$ atmosphere for $72 \mathrm{~h}$. Ten microliters of Alamar Blue $(12.5 \mathrm{mg}$ rezasurin dissolved in one litre of distilled water) were then added to each well and incubation continued for a further four hours. The plate was read using a Spectramax Gemini XS microplate fluorometer (Molecular Devices Cooperation, Sunnyvale, CA, USA) at an excitation wavelength of $536 \mathrm{~nm}$ and emission wavelength of $588 \mathrm{~nm}$ (Räz et al., 1997). The definition of the antitrypanosomal activity used was: $\mathrm{IC}_{50}<1.0 \mu \mathrm{g} / \mathrm{ml}$ - strong activity, $1.0-5.0 \mu \mathrm{g} / \mathrm{ml}$ - moderate activity, $5.0-10 \mu \mathrm{g} / \mathrm{ml}$ mild activity, and $\mathrm{IC}_{50}>10 \mu \mathrm{g} / \mathrm{ml}$ - inactive. Melarsoprol $\left(\mathrm{IC}_{50} 0.002 \pm 0.0001 \mu \mathrm{g} / \mathrm{ml}\right.$ ) was used as the standard drug.

The in vitro antileishmanial assay was carried out according to the procedure of Kaminsky et al. (1996). Leishmania donovani MHOM-ET-67/ 82 strain was maintained in the Syrian golden hamster (Mesocricetus auratus). Amastigotes were collected from the spleen of an infected hamster and grown in axenic culture at $37^{\circ} \mathrm{C}$ in slime mould (Dictyostelium discoideum) (SM) medium supplemented with $10 \%$ heat inactivated foetal bovine serum (FBS) at $\mathrm{pH} 5.4$ under the atmosphere of $5 \% \mathrm{CO}_{2}$ in air. $100 \mu \mathrm{l}$ of culture medium with $10^{5}$ amastigotes from axenic culture with a serial drug dilution were seeded in 96-well microtitre plates. After $72 \mathrm{~h}$ of incubation the plates were inspected under inverted microscope to assure growth of the controls and sterile conditions. $10 \mu \mathrm{l}$ of Alamar Blue (12.5 mg rezasurin dissolved in one litre of distilled water) were then added to each well and the plates incubated for another two hours. Miltefosine was used as the standard drug. Then the plates were read with a Spectramax Gemini XS microplate fluorometer using an excitation wavelength of $536 \mathrm{~nm}$ and an emission wavelength of $588 \mathrm{~nm}$. The definition of the antileishmanial activity used was: $\mathrm{IC}_{50}<1.0 \mu \mathrm{g} / \mathrm{ml}$ - strong activity; 1.0 $-5.0 \mu \mathrm{g} / \mathrm{ml}$ - moderate activity; $5.0-10.0 \mu \mathrm{g} / \mathrm{ml}$ - mild activity; and $\mathrm{IC}_{50}>10 \mu \mathrm{g} / \mathrm{ml}$ - inactive. Miltefosine $\left(\mathrm{IC}_{50} 0.11 \pm 0.001 \mu \mathrm{g} / \mathrm{ml}\right)$ was used as the standard drug.

\section{Cytotoxicity and drug selectivity index}

The in vitro cytotoxicity assay was carried out according to the procedure described by Kaminsky et al. (1996). Rat skeletal myoblast (L-6) cells were maintained as stock culture in RPMI 1640 medium $+10 \%$ FBS $+1 \%$ Lglutamine $(200 \mathrm{mM}) . \quad 100 \mu \mathrm{l}$ of cell suspension consisting of $4 \times 10^{4}$ cells $/ \mathrm{ml}$ were added into each well of columns 1 and 2,4 and 5, 7 and 8 , and 10 and 11 of a 96-well micro-titre plate (Costar ${ }^{\mathrm{TM}}$, Corning Inc.). Cells were allowed to attach for $24 \mathrm{~h}$, the medium removed completely the next morning, and $100 \mu \mathrm{l}$ of fresh medium added to all wells except in row $\mathrm{H}$. Four drugs were tested on one plate (drug 1 column 13 , drug 2 column 4-6, drug 3 column 7-9 and drug 4 column 10-12). A serial dilution factor of 1:3 was used to give concentrations in the range $270-0.37 \mu \mathrm{g} / \mathrm{ml}$. Wells in row A served as controls wells without any drugs. The plates were incubated for $72 \mathrm{~h}$ at $37^{\circ} \mathrm{C}$ in $5 \% \mathrm{CO}_{2}$ in air. Podophyllotoxin was used as the standard drug. The fluorescent dye, Alamar blue $(10 \mu \mathrm{l})$ (Trek Diagnostic Systems, East Grinstead, UK), was added to each well and the plates incubated for another two hours. The plates were read using a fluorescence plate reader at excitation and emission wavelengths of 536 and $588 \mathrm{~nm}$, respectively. The definition of the cytotoxicity used was: $\mathrm{CC}_{50}<1.0 \mu \mathrm{g} / \mathrm{ml}$ - high cytotoxicity; $\mathrm{CC}_{50} 1.0-10.0 \mu \mathrm{g} / \mathrm{ml}$ - moderate; $\mathrm{CC}_{50} 10.0$ $30.0 \mu \mathrm{g} / \mathrm{ml}$ - mild; and $\mathrm{CC}_{50}>30 \mu \mathrm{g} / \mathrm{ml}$ - non 
cytotoxic. Podophyllotoxin $\left(\mathrm{CC}_{50} 0.009 \pm 0.00003\right.$ $\mu \mathrm{g} / \mathrm{ml}$ ) was used as standard cytotoxin.

\section{Data analysis}

The antitrypanosomal assay data was transferred into a graphic programme (Softmax Pro, Molecular Devices Corporation, Sunnyvale, CA, USA) to generate sigmoidal inhibition curves from which $\mathrm{IC}_{50}$ value for each drug was calculated. The antileishmanial assay data was transferred into a graphic programme to generate sigmoidal inhibition curves from which $\mathrm{IC}_{50}$ value for each drug was calculated. The cytotoxicity data was analysed using the plate reader software (Softmax, Molecular Devices Corporation, Sunnyvale, CA, USA) and the $\mathrm{CC}_{50}$ value of each drug calculated.

\section{Results}

Out of 25 plant extracts, 17 showed good activity against $P$. falciparum $\mathrm{K} 1$ strain $\left(\mathrm{IC}_{50} \leq 5.1 \mu \mathrm{g} / \mathrm{ml}\right.$ ), 3 were moderately active $\left(\mathrm{IC}_{50} 5.2-10 \mu \mathrm{g} / \mathrm{ml}\right.$ ) while the remaining 5 were inactive $\left(\mathrm{IC}_{50}>10\right.$ $\mu \mathrm{g} / \mathrm{ml}$ ) (Table 2). Ten extracts were of particular interest since they had $\mathrm{IC}_{50}$ values of $\leq 1 \mu \mathrm{g} / \mathrm{ml}$ : the $n$-hexane extract of $A$. annua leaf $\left(\mathrm{IC}_{50} 0.04\right.$ $\mu \mathrm{g} / \mathrm{ml}$, SI > 2,250.0), the dichloromethane and methanol extracts of $A$. kummeriae stem-bark $\left(\mathrm{IC}_{50}\right.$ $0.31 \mu \mathrm{g} / \mathrm{ml}$, SI 187.74 and 173.55 respectively), methanol and dichloromethane of A. kummeriae root-bark $\left(\mathrm{IC}_{50} 0.35,0.36 \mu \mathrm{g} / \mathrm{ml}\right.$ and SI 175.43, 29.17, respectively), the ethanol extract of $A$. annua seeds $\left(\mathrm{IC}_{50} 0.65 \mu \mathrm{g} / \mathrm{ml},>138.5\right)$, the ethanol extract of $D$. natalensis root-bark $\left(\mathrm{IC}_{50} 1.06 \mu \mathrm{g} /\right.$ $\mathrm{ml}$, SI 17.92), and ethanol extract of P. microcarpa root-bark $\left(\mathrm{IC}_{50} 1.13 \mu \mathrm{g} / \mathrm{ml}\right.$, SI 79.65). Others with good activity $(\leq 2 \mu \mathrm{g} / \mathrm{ml})$ include the ethanol extract of $D$. natalensis stem-bark $\left(\mathrm{IC}_{50}\right.$ $1.42 \mu \mathrm{g} / \mathrm{ml}$, SI 62.61), the ethanol extract of $N$. mitis tuber $\left(\mathrm{IC}_{50} 1.52 \mu \mathrm{g} / \mathrm{ml}\right.$, SI 14.40), petroleum ether extract of A. kummeriae stem-bark ( $\mathrm{IC}_{50} 1.85$ $\mu \mathrm{g} / \mathrm{ml}$, SI 11.89), and the ethanol extract of $M$. senegalensis $\left(\mathrm{IC}_{50} 2.05 \mu \mathrm{g} / \mathrm{ml}, \mathrm{SI}>43.9\right)$. The $\mathrm{IC}_{50}$ of the crude extracts were compared with that of the standard drugs chloroquine $\left(\mathrm{IC}_{50}=0.063\right.$ $\mu \mathrm{g} / \mathrm{ml}$ ) and artemisinin $\left(\mathrm{IC}_{50}=0.002 \mu \mathrm{g} / \mathrm{ml}\right)$. The most promising extract in this assay was the $n$-hexane extract of the leaves of $A$. annua which exhibited 0.6 fold and 20- fold activity higher than that of chloroquine and lower than that of artemisinin, respectively whereas, the methanolicleavesextract of $A$. kummeriae showed 1.9 fold and 60.0 fold activity closer to that of chloroquine and artemisinin, respectively. The stem and roots dichloromethane and methanolic extracts of A. kummeriae were also promising showing between 4.9 and 5.7 fold and 155 and 180 fold activity closer to that of chloroquine and artemisinin, respectively. The rest were comparatively far less active as compared to the standard drugs (Table 3).

Out of 25 plant extracts, nine were inactive against $T$. $b$. rhodesiense, 9 others showed weak anti-trypanosomal activity with $\mathrm{IC}_{50}$ values ranging between 25 and $10.60 \mu \mathrm{g} /$ $\mathrm{ml}$ while seven had moderate activity $\left(\mathrm{IC}_{50}\right.$ $\leq 7.40 \mu \mathrm{g} / \mathrm{ml}$ ) (Table 2). Six extracts were of particular interest since the anti-trypanosomal activity was $\leq 3 \mu \mathrm{g} / \mathrm{ml}$. The methanol extract of the leaves and the dichloromethane, chloroform and ethanol extracts of stem-bark and rootbark of $A$. kummeriae had the best activity with $\mathrm{IC}_{50}$ values of $2.3-2.8 \mu \mathrm{g} / \mathrm{ml}$ and SI 3.75-26.70, followed by the methanol extract of root bark of P. microcarpa ( $\mathrm{IC}_{50} 5.40 \mu \mathrm{g} / \mathrm{ml}$, SI 7.26) and the petroleum ether extract of A. kummeriae stembark $\left(\mathrm{IC}_{50} 7.4 . \mu \mathrm{g} / \mathrm{ml}, \mathrm{SI} 2.97\right)$. The rest of the extracts were inactive. The $\mathrm{IC}_{50}$ values of crude extracts were compared with that of the standard drug melarsoprol $\left(\mathrm{IC}_{50}=0.002 \mu \mathrm{g} / \mathrm{ml}\right)$. The $\mathrm{IC}_{50}$ values indicate that, extracts were relatively far less active as compared to the standard drug (Table 3).

In the antileishmanial assay, 20 out of 25 plant extracts were inactive against $L$. donovani amastigotes $\left(\mathrm{IC}_{50}>10 \mu \mathrm{g} / \mathrm{ml}\right)$ while 5 exhibited mild anti-leishmanial activity (Table 2). The $n$-hexane extract of the leaves of $A$. annua was the most active extract of all with an $\mathrm{IC}_{50}$ value of $6.40 \mu \mathrm{g} / \mathrm{ml}$ and SI >14.06, followed by others but with narrow selectivity, these are the: ethanol extract of $N$. mitis tuber $\left(\mathrm{IC}_{50} 8.8\right.$ $\mu \mathrm{g} / \mathrm{ml}$, SI 2.59), the methanol, petroleum ether and dichloromethane extracts of A. kummeriae leaves $\left(\mathrm{IC}_{50} 9.25 \mu \mathrm{g} / \mathrm{ml}\right.$, SI 3.2), stem-bark ( $\mathrm{IC}_{50}$ $9.74 \mu \mathrm{g} / \mathrm{ml}$, SI 2.26), and root-bark ( $\mathrm{IC}_{50} 9.79$ $\mu \mathrm{g} / \mathrm{ml}$, SI 1.07), respectively. Comparisons of the $\mathrm{IC}_{50}$ of the crude extracts with the $\mathrm{IC}_{50}$ of the standard drug miltefosine $\left(\mathrm{IC}_{50}=0.11 \mu \mathrm{g} / \mathrm{ml}\right)$ indicated moderate activities. The $\mathrm{IC}_{50}$ values of crude extracts were between 58.2 and $>272.7$ fold lower compared to that of the standard drug. Thus, $n$-hexane extract of $A$. annua leaves (58.2 fold), ethanol extract of N. mitis tuber (80.0 fold), the methanol, petroleum ether and dichloromethane extracts of A. kummeriae leaves (84.1->272.7 fold), stem-bark (88.5-176.4 fold), and root-bark (89.0-132.3 fold); and the dichloromethane extract of $A$. chloropterus leaves (106 fold), the remaining crude extracts were comparatively far less active as compared to the standard drug (Table 3). 
Table 2: Antiplasmodial, anti-trypanosomal, anti-leishmanial and cytotoxicity activity plus selectivity indices of extracts of selected Tanzanian medicinal plants

\begin{tabular}{|c|c|c|c|c|c|c|c|c|}
\hline \multirow[t]{2}{*}{ Extracts } & \multicolumn{2}{|c|}{ Rat L-6 cells } & \multicolumn{2}{|c|}{ P. falciparum $\mathrm{K} 1$} & \multicolumn{2}{|c|}{ T.b. rhodesiense } & \multicolumn{2}{|c|}{ L. donovani } \\
\hline & $\begin{array}{l}\mathrm{CC}_{50} \quad(\mu \mathrm{g} / \\
\mathrm{ml})\end{array}$ & SI & $\mathrm{IC}_{50}(\mu \mathrm{g} / \mathrm{ml})$ & SI & $\mathrm{IC}_{50}(\mu \mathrm{g} / \mathrm{ml})$ & SI & $\mathrm{IC}_{50}(\mu \mathrm{g} / \mathrm{ml})$ & SI \\
\hline \multicolumn{9}{|l|}{ A. kummeriae } \\
\hline $\mathrm{L}(\mathrm{PE})$ & $72.0 \pm 3.10$ & 8,000 & $4.65 \pm 0.15$ & 15.48 & $21.70 \pm 3.47$ & 3.32 & $>30$ & $>2.40$ \\
\hline $\mathrm{L}(\mathrm{DCM})$ & $70.6 \pm 2.56$ & 7,844 & $6.70 \pm 1.53$ & 10.54 & $23.50 \pm 1.90$ & 3.00 & $>30$ & $>2.35$ \\
\hline $\mathrm{L}(\mathrm{MeOH})$ & $30.0 \pm 0.74$ & 3,333 & $0.12 \pm 0.01$ & 250.0 & $2.50 \pm 0.19$ & 12.00 & $9.25 \pm 0.54$ & 3.2 \\
\hline ST (PE) & $22.0 \pm 3.00$ & 2,444 & $1.85 \pm 0.55$ & 11.89 & $7.40 \pm 0.53$ & 2.97 & $9.74 \pm 1.82$ & 2.26 \\
\hline ST (DCM) & $58.2 \pm 2.80$ & 6,467 & $0.31 \pm 0.05$ & 187.74 & $2.50 \pm 0.24$ & 23.28 & $18.00 \pm 0.42$ & 3.23 \\
\hline $\mathrm{ST}(\mathrm{MeOH})$ & $53.8 \pm 2.40$ & 5,978 & $0.31 \pm 0.04$ & 173.55 & $2.50 \pm 0.10$ & 21.52 & $19.41 \pm 1.66$ & 2.77 \\
\hline RT (PE) & $34.1 \pm 3.20$ & 3,789 & $2.51 \pm 0.11$ & 13.59 & $14.10 \pm 0.45$ & 2.42 & $14.55 \pm 1.1$ & 2.34 \\
\hline RT (DCM) & $10.5 \pm 0.62$ & 1,167 & $0.36 \pm 0.06$ & 29.17 & $2.80 \pm 0.23$ & 3.75 & $9.79 \pm 2.5$ & 1.07 \\
\hline RT $(\mathrm{MeOH})$ & $61.4 \pm 3.97$ & 6,822 & $0.35 \pm 0.04$ & 175.43 & $2.30 \pm 0.43$ & 26.70 & $12.38 \pm 1.12$ & 4.94 \\
\hline \multicolumn{9}{|c|}{ A. chloropterus } \\
\hline $\mathrm{L}(\mathrm{PE})$ & $>90$ & $>10,000$ & $15.87 \pm 1.28$ & $>5.67$ & $47.40 \pm 1.51$ & $>1.9$ & $>30$ & $>3.00$ \\
\hline $\mathrm{L}(\mathrm{DCM})$ & $77.3 \pm 2.82$ & 8,589 & $5.50 \pm 2.7$ & 14.05 & $29.40 \pm 1.90$ & 2.63 & $11.66 \pm 1.51$ & 6.63 \\
\hline $\mathrm{L}(\mathrm{MeOH})$ & $80.8 \pm 4.03$ & 8,978 & $15.43 \pm 1.42$ & 5.23 & $42.90 \pm 1.30$ & 1.88 & $28.80 \pm 1.21$ & 2.81 \\
\hline ST (PE) & $88.1 \pm 1.90$ & 9,789 & $16.68 \pm 0.10$ & 5.28 & $46.40 \pm 0.94$ & 1.90 & $>30$ & $>2.94$ \\
\hline ST (DCM) & $82.5 \pm 4.20$ & 9,167 & $7.23 \pm 1.45$ & 11.41 & $35.80 \pm 1.46$ & 2.30 & $14.57 \pm 1.36$ & 5.66 \\
\hline RT (PE) & $>90$ & $>10,000$ & $10.81 \pm 0.38$ & 8.33 & $40.20 \pm 2.42$ & 2.24 & $>30$ & $>3.00$ \\
\hline $\mathrm{RT}(\mathrm{DCM})$ & $64.7 \pm 6.90$ & 7,189 & $5.06 \pm 0.92$ & 12.79 & $28.30 \pm 0.80$ & 2.29 & $>30$ & $>2.16$ \\
\hline RT $(\mathrm{MeOH})$ & $>90$ & $>10,000$ & $43.83 \pm 1.27$ & 2.05 & $68.20 \pm 0.80$ & 1.32 & $>30$ & $>3.00$ \\
\hline \multicolumn{9}{|l|}{ P. microcarpa } \\
\hline ST (EtOH) & $>90$ & $>10,000$ & $4.33 \pm 1.44$ & 20.79 & $5.40 \pm 0.64$ & 7.26 & $29.9 \pm 4.19$ & $>3.00$ \\
\hline $\mathrm{RT}(\mathrm{EtOH})$ & $>90$ & $>10,000$ & $1.13 \pm 0.16$ & 79.65 & $11.60 \pm 1.74$ & 7.38 & $>30$ & $>5.45$ \\
\hline \multicolumn{9}{|l|}{ D. natalensis } \\
\hline ST (EtOH) & $88.9 \pm 1.10$ & 9,878 & $1.42 \pm 0.54$ & 62.61 & $10.70 \pm 1.99$ & 16.46 & $19.00 \pm 3.27$ & 2.90 \\
\hline $\mathrm{RT}(\mathrm{EtOH})$ & $19.0 \pm 0.38$ & 2,111 & $1.06 \pm 0.20$ & 17.92 & $12.10 \pm 0.38$ & 1.64 & $29.7 \pm 3.52$ & 0.64 \\
\hline \multicolumn{9}{|c|}{ M. senegalensis } \\
\hline $\mathrm{RT}(\mathrm{EtOH})$ & $>90.00$ & $>10,000$ & $2.05 \pm 0.68$ & $>43.9$ & $12.2 \pm 1.6$ & $>7.4$ & $16.5 \pm 2.32$ & $>5.50$ \\
\hline \multicolumn{9}{|l|}{ N. mitis } \\
\hline $\mathrm{T}(\mathrm{EtOH})$ & $22.8 \pm 2.57$ & 2,533 & $1.58 \pm 0.75$ & 14.4 & $12.4 \pm 0.92$ & 1.80 & $8.8 \pm 1.06$ & 2.59 \\
\hline \multicolumn{9}{|l|}{ A. апnua } \\
\hline $\mathrm{L}\left(n-\mathrm{C}_{6} \mathrm{H}_{14}\right)$ & $>90.00$ & $>10,000$ & $0.04 \pm 0.03$ & $>2,250$ & $15.3 \pm 2.66$ & $>5.9$ & $6.4 \pm 0.6$ & $>14.06$ \\
\hline $\mathrm{S}(\mathrm{EtOH})$ & $>90.00$ & $>10,000$ & $0.65 \pm 0.17$ & $>138.5$ & $27.2 \pm 1.9$ & $>3.3$ & $>30.00$ & $>3.00$ \\
\hline
\end{tabular}

$\mathrm{L}$ - leaves, ST - stem bark, RT - root bark, S - seeds, T - tuber, PE - petroleum ether, DCM - dichloromethane, $n$ - $\mathrm{C}_{6} \mathrm{H}_{14}-$ n-hexane, $\mathrm{MeOH}-$ methanol, $\mathrm{CC}_{50} 0.009 \pm 0.00001 \mu \mathrm{g} / \mathrm{ml}$ for podophyllotoxin, $\mathrm{IC}_{50} 0.063 \pm 0.03$ and $0.002 \pm 0.0001 \mu \mathrm{g} /$ $\mathrm{ml}$ for chloroquine and artemisinin, respectively, $\mathrm{IC}_{50} 0.002 \pm 0.0001 \mu \mathrm{g} / \mathrm{ml}$ for melarsoprol, $\mathrm{IC}_{50} 0.11 \pm 0.001 \mu \mathrm{g} / \mathrm{ml}$ for Miltefosine. 
Table 3: Comparison of extracts $\mathrm{IC}_{50}$ values with those of standard drugs

\begin{tabular}{|c|c|c|c|c|}
\hline Extracts & $\begin{array}{l}\underline{I C}_{50} \frac{\text { Extract }}{\text { IC }} \\
\text { Chloroquine }\end{array}$ & $\begin{array}{l}\underline{I C}_{50} \frac{\text { Extract }}{\text { IC }} \\
{ }_{-0} \text { Artemisinin }\end{array}$ & $\begin{array}{l}\underline{\text { IC }}_{50} \text { Extract } \\
\text { IC }_{-0} \text { Melarsoprol }\end{array}$ & $\underline{\text { IC }_{50}} \frac{\text { Extract }}{\text { IC }}$ \\
\hline \multicolumn{5}{|l|}{ A. kummeriae } \\
\hline $\mathrm{L}(\mathrm{PE})$ & 73.8 & $2,325.0$ & $10,850.0$ & $>272.7$ \\
\hline $\mathrm{L}(\mathrm{DCM})$ & 106.3 & $3,350.0$ & $11,750.0$ & $>272.7$ \\
\hline $\mathrm{L}(\mathrm{MeOH})$ & $1.9^{*}$ & $60.0^{*}$ & $1,250.0$ & 84.1 \\
\hline ST (PE) & 29.4 & 925.0 & $3,700.0$ & 88.5 \\
\hline ST (DCM) & $4.9^{*}$ & 155.0 & $1,250.0$ & 163.6 \\
\hline ST (MeOH) & $4.9^{*}$ & 155.0 & $1,250.0$ & 176.4 \\
\hline RT (PE) & 39.8 & $1,255.0$ & $7,050.0$ & 132.3 \\
\hline RT (DCM) & $5.7^{*}$ & 180.0 & $1,400.0$ & 89.0 \\
\hline $\mathrm{RT}(\mathrm{MeOH})$ & $5.6^{*}$ & 175.0 & $1,150.0$ & 112.5 \\
\hline \multicolumn{5}{|l|}{ A. chloropterus } \\
\hline $\mathrm{L}(\mathrm{PE})$ & 251.9 & $7,935.0$ & $23,700.0$ & $>272.7$ \\
\hline L (DCM) & 87.3 & $2,750.0$ & $14,700.0$ & 106.0 \\
\hline $\mathrm{L}(\mathrm{MeOH})$ & 244.9 & $7,715.0$ & $21,450.0$ & 261.8 \\
\hline $\mathrm{ST}(\mathrm{PE})$ & 264.8 & $8,340.0$ & $23,200.0$ & $>272.7$ \\
\hline ST (DCM) & 114.8 & $3,615.0$ & $17,900.0$ & 132.5 \\
\hline RT (PE) & 171.6 & $5,405.0$ & $20,100.0$ & $>272.7$ \\
\hline RT (DCM) & 80.3 & $2,530.0$ & $14,150.0$ & $>272.7$ \\
\hline RT (MeOH) & 695.7 & $21,915.0$ & $34,100.0$ & $>272.7$ \\
\hline \multicolumn{5}{|l|}{ P. microcarpa } \\
\hline ST (EtOH) & 68.7 & $2,165.0$ & $2,700.0$ & 271.8 \\
\hline RT (EtOH ) & 17.9 & 565.0 & $5,800.0$ & $>272.7$ \\
\hline \multicolumn{5}{|l|}{ D. natalensis } \\
\hline ST (EtOH) & 22.5 & 710.0 & $5,350.0$ & 172.7 \\
\hline RT (EtOH) & 16.8 & 530.0 & $6,050.0$ & 270.0 \\
\hline \multicolumn{5}{|l|}{ M. senegalensis } \\
\hline RT (EtOH) & 32.5 & $1,025.0$ & $6,100.0$ & 150.0 \\
\hline \multicolumn{5}{|l|}{ N. mitis } \\
\hline $\mathrm{T}(\mathrm{EtOH})$ & 25.1 & 790.0 & $6,200.0$ & 80.0 \\
\hline \multicolumn{5}{|l|}{ А. апnиа } \\
\hline $\mathrm{L}\left(n-\mathrm{C}_{6} \mathrm{H}_{14}\right)$ & $0.6^{*}$ & $20.0^{*}$ & $7,650.0$ & 58.2 \\
\hline $\mathrm{S}(\mathrm{EtOH})$ & $10.3^{*}$ & 325.0 & $13,600.0$ & $>272.7$ \\
\hline
\end{tabular}

\section{Discussion}

Our results show that, ten extracts presented strong to moderate antiplasmodial activity with $\mathrm{IC}_{50}$ in between 0.04 and $2.05 \mu \mathrm{g} / \mathrm{ml}$. These were the leaves and seed extracts of Artemisia annua, the leaves, stem and root bark extracts of Annickia kummeriae, root and stem bark extract of Drypetes natalensis, root bark extract of Pseudospondias microcarpa, tuber extract of Neurautanenia mitis and the root bark extract of Maytenus senegalensis. All this confirms their traditional use as antimalarial plants. Our results confirmed that the methanol extracts of the leaves, stem-bark, root-bark and dichloromethane extract of the stem-bark of A. kummeriae have high in vitro antiplasmodial activity against $P$. falciparum $\mathrm{K} 1$ strain $\left(\mathrm{IC}_{50}\right.$ $0.12-0.36 \mu \mathrm{g} / \mathrm{ml}$ ) and high selectivity (SI 29.17250.0). In addition to that, the dichloromethane and methanolic extracts of the stem and roots of $A$. kummeriae showed $\mathrm{IC}_{50}$ values which were between 4.9 and 5.7 fold and 155 and 180 fold closer antimalarial activity to that of chloroquine and artemisinin, respectively. However, the petroleum ether and other dichloromethane extracts exhibited moderate to mild activity $\left(\mathrm{IC}_{50}\right.$ $1.85-6.70 \mu \mathrm{g} / \mathrm{ml}$ ) and low selectivity (SI 10.5411.89). An exceptional good activity ( $\mathrm{IC}_{50} 0.36$ $\mu \mathrm{g} / \mathrm{ml}$ ) and moderate selectivity (SI 29.17) was found in dichloromethane extract of the rootbark, while a moderate to mild anti-leishmanial and anti-trypanosomal activity of $A$. kummeriae extracts were noted. Annickia kummeriae is a rare plant species that has not been reported outside Tanzania and should be conserved. The antiplasmodial principles of A. kummeriae are currently under investigation.

The hexane extract of $A$. annua leaves showed the highest in vitro antiplasmodial activity $\left(\mathrm{IC}_{50} 0.04 \mu \mathrm{g} / \mathrm{ml}\right.$ ) and selectivity index (SI $>2,250)$ confirming its efficacy and safety (Tawfiq et al., 2004). Although the cytotoxicity of hexane leaf and ethanol seed extracts are the same, the activity and selectivity of the latter are lower, suggesting reduced amount of the active principles. 
P. microcarpa root-bark extract has high in vitro antiplasmodial activity against $P$. falciparum $\mathrm{K} 1$ strain $\left(\mathrm{IC}_{50} 1.13 \mu \mathrm{g} / \mathrm{ml}\right.$ ) and good selectivity (SI 79.65). Unfortunately, P. microcarpa showed mild anti-trypanosomal activity $\left(\mathrm{IC}_{50} 5.40 \mu \mathrm{g} /\right.$ $\mathrm{ml}$, SI 7.26). Similar findings have been reported from Congo Brazzaville (Mbatchi et al., 2006). Extract of $P$. microcarpa was inactive against Leishmania donovani parasites. Stem-bark and root-bark extracts of Drypetes natalensis exhibited high in vitro antiplasmodial activity against $P$. falciparum $\mathrm{K} 1$ strain $\left(\mathrm{IC}_{50} 1.42\right.$ and $1.06 \mu \mathrm{g} / \mathrm{ml}$, respectively) and good selectivity (SI 62.61 and 17.92, respectively). Maytenus senegalensis showed moderate in vitro antiplasmodial activity against $P$. falciparum $\mathrm{K} 1$ strain $\left(\mathrm{IC}_{50} 2.05 \mu \mathrm{g} / \mathrm{ml}\right)$ and good selectivity (SI > 43.9). Unfortunately, $M$. senegalensis extracts were inactive against $T$. b. rhodesiense and L. donovani, respectively. Other studies have shown that methanol extract of M. senegalensis has significant antiplasmodial activity (Gessler et al., 1995; Rukunga et al., 2009). Neurautanenia mitis tuber extract exhibited high in vitro antiplasmodial activity against P. falciparum $\mathrm{K} 1$ strain $\left(\mathrm{IC}_{50} 1.52 \mu \mathrm{g} / \mathrm{ml}\right.$ ) and a moderate selectivity (SI 14.43).

The high percentage $(68 \%)$ of extracts with good antiplasmodial with moderate antitrypanosomal $(20 \%)$ and mild anti-leishmanial activity $(20 \%)$ suggests that these plants may be useful in the traditional management of malaria and other protozoal diseases. In view of the high antiplasmodial activity and good selectivity of Artemisia annua extract just 0.6 fold higher activity than chloroquine and 11.8 fold lower activity than artemisinin, and the usually envisaged ten-fold improvement in biological activity of the isolated pure compound, cost benefit analysis discourages the purification downward to the pure artemisinin compound. The crude extract is itself with enough antiplasmodial activity and the required safety to serve as an antimalarial drug. However, quality control of the crude drug/extract must be undertaken and therapeutic indices determined. The in vitro anti-protozoal activity and cytotoxicity of A. kummeriae, P. microcarpa, and $D$. natalensis are being reported here for the first time, and bioassay-guided isolation of bioactive principles should be undertaken to provide new anti-parasitic drugs or lead compounds for anti-malarial anti-trypanosomal and anti-leishmanial drug development. Since Neurautanenia mitis is an insecticidal and a potent fish poison with moderate selectivity, this plant poses health risks to users and there is a strong need for further pharmacological investigations to elucidate its toxic potential and principles for possible evaluation and development of new insecticides.

In African communities, medicinal plants have always been used for the treatment of malaria and other ailments. However, without a scientific validation the traditional preparations cannot be integrated in "modern" medicine. This study has highlighted six promising plants for further antiplasmodial investigations, and the determination of their active constituents, with a view to rationalize and optimize their utilization.

\section{Acknowledgements}

We are grateful to Mr. Leonard B. Mwasumbi who identified the plant materials. The German Academic Exchange Program, Basel Canton Stipend Commission, Eastern Africa Network for Trypanosomiasis, International Foundation for Science, the National Institute for Medical Research (Tanzania), Kenyatta University and the Swiss Tropical Institute are gratefully acknowledged for supporting this project in one way or another.

\section{Received 2 May 2009}

Revised 10 August 2009

Accepted 23 August 2009

\section{References}

Abraham, D.J., Trojanek, J., Münzing, H.P., Fong, H.H.S. \& Farnsworth, N.R. (2006) Structure elucidation of maytenonic acid, a new triterpene from Maytenus senegalensis (celastraceae). Journal of Pharmaceutical Sciences 60, 1085-1087.

Agbaje, E.O. \& Onabanjo, A.O. (1991) The effects of extracts of Enantia chlorantha in malaria. Annals of Tropical Medicine and Parasitology 85, 585-590.

Akendengue, B., Louis, A.M. (1994) Medicinal plants used by the Masango people in Gabon. Journal of Ethnopharmacology 41, 193-200.

Atindehou, K.K., Schmid, C, Brun, R., Koné, M.W. \& Traore, D. (2004) Antitrypanosomal and Antiplasmodial activity of medicinal plants from Côte d'Ivoire. Journal of Ethnopharmacology 90, 221-227. 
Baltz, T., Baltz, D., Giroud, C. \& Crokett, J. (1985) Cultivation in semi-defined medium of animal infective forms of Trypanosoma brucei, T. equiperdum, T. evansi, T. rhodesiense and T. gambiense. The European Molecular Biology Organization Journal 4, 1273-1277.

Betti, J.L. (2002) Medicinal plants sold in Yaoundé markets, Cameroon. African Study Monographs 23, 47-64.

Bouquet, A. \& Debray, M. (1974) Plantes médicinales de la Côte d'Ivoire. Mémoires Office de la Recherche Scientifique et Technique d'Outre-Mer (O.R.S.T.O.M), 32 (éd), Paris, 232.

Bryceson, A.D.M. (1996) Leishmaniasis. In: Manson's Tropical Diseases, $20^{\text {th }}$ Edn, Cook, G. (ed.), W. B. Suanders \& Co. New Delhi, 65, 1213.

Buzas, A., Osowiecki, M. \& Regnier, C. (1959) Sur la présence de quinidine (et l'hydroquinidine) dans l'écorce de l'Enantia polycarpa. Comptes Rendus Académie des Sciences 248, 2791-2793.

Buzas, A., Egnell, C. \& Orsay, F. (1965) Sur la présence de quinidine à côté d'alcalöides berberiniques dans les écorces d'Enantia pilosa et E. polycarpa. Annales Pharmaceutiques de France 23, 351-354.

Dhawan, B.N., Patnaik, G.K., Rastogi, R.P., Singh, K.K. \& Tandon, J.S. (1977) Screening of Indian plants for biological activity VI. Indian Journal of Experimental Biology 15, 208-219.

Gessler, M.C., Msuya, D.E.., Nkunya, M.H.H., Mwasumbi, L.B., Schar, A.., Heinrich, M. \& Tanner, M. (1995) Traditional healers in Tanzania: the treatment of malaria with plant remedies. Journal of Ethnopharmacology $48,131-144$.

Hussein, G., Nakamura, N., Meselhy, M.R. \& Hattori, M. (1999) Phenolics from Maytenus senegalensis. Phytochemistry 50, 689-694.

Joseph, C.C., Ndoile, M.M., Malima, R.C. \& Nkunya, M.H. (2004) Larvicidal and mosquitocidal extracts, a coumarin, isoflavonoids and pterocarpans from Neorautanenia mitis. Transactions of the Royal Society of Tropical Medicine and Hygiene 98, 451-5.

Jössang, A., Leboeuf, M. \& Cave, A. (1977a) Alcalöides des Annonacées. XVII. Alcalöides de l'Enantia polycarpa Engl. et Diels. Planta Medica 32, 249-257.
Jössang, A., Leboeuf, M. \& Cave, A. (1977b) La polycarpine, nouvelle alcalöide isoquinolique de l'Enantia polycarpa Engler et Diels. Comptes Rendus de l'Académie des Sciences 284, 567-569.

Kaminsky, R., Schmid, C. \& Brun, R. (1996) An in vitro selectivity index for evaluation of cytotoxicity of anti-trypanosomal compounds. In Vitro Toxicology 9, 315324.

Leboeuf, M. \& Cave, A. (1972) Alcalöides des Annonacées. Plantes Médicinales et Phytothérapie 6, 87-90.

Marsden, P.D.(1996) American Trypanosomiasis. In: Manson's Tropical Diseases, $20^{\text {th }}$ Edn, Cook, G. (ed.) W.B. Saunders \& Co., New Delhi, 64, 1197.

Matile, H. \& Pink, J.R.L. (1990) Plasmodium falciparum malaria parasite cultures and their use in immunology. In: Immunological Methods, Lefkovits, I., Pernis, B. (eds). Academic Press, San Diego, 221-234.

Mbatchi, S.F., Mbatchi, B., Banzaouzi, J.T., Bansimba, T., Nsonde Ntandou, G.F., Ouamba, J-M., Berry, A. \& BenoitVical, F. (2006) In vitro antiplasmodial activity of 18 plants used in Congo Brazzaville traditional medicine. Journal of Ethnopharmacology 104, 168-174.

Nkeh, B., Chungag, A., Njamen, D., Dongmo, A.B., Wandji, J., Nguelefack, T.B., Wansi, J.D., Kamanyi, A. \& Fomum, Z.T. (2001) Anti-inflammatory and analgesic properties of the stem extract of Drypetes molunduana Pax and Hoffm. (Euphorbiaceae) in rats. Pharmaceutical and Pharmacology Letters 11, 61-63.

Nkeh, B., Njamen, D., Wandji, J., Fomum, Z.T., Dongmo, A., Nguelefack, T.B., Wansi, J.D. \& Kamanyi, A. (2003) Anti-inflammatory and analgesic effects of drypemolundein A, a sesquiterpene lactone from Drypetes molunduana. Pharmaceutical Biology , 41, 26-30.

Noumi, E. \& Yomi, A. (2001) Medicinal plants used for intestinal diseases in Mbalmayo region, Central Province, Cameroon. Fitoterapia 72 , 246-254.

Olliaro P. \& Cattani J. (1996) Malaria, the submerged disease. Journal of the American Medical Association 275, 230.

Räz, B., Iten, M., Grether, Y., Kaminsky, R. \& Brun, R. (1997) The Alamar blue assay to determine drug sensitivity of African 
trypanosomes (T. $b$. rhodesiense and T. $b$. gambiense) in vitro. Acta Tropica 68, 139147.

Rukunga, G.M., Gathirwa, J.W., Omar, S.A., Muregi, F.W., Mutharira, C.N., Kirira, P.G. Mungai, G.M. \& Kofi-Tsekpo, W.M. (2009) Antiplasmodial activity of the extracts of some Kenyan medicinal plants. Journal of Ethnopharmacology 121, 282-285.

Sandberg, F. \& Cronlund, A. (1977) Proceedings of the $3^{\text {rd }}$ Asian Symposium on Medicinal Plants and Spices. Colombo, Sri Lanka 3, 178-197.

Swiss Invest Forum (2007) Accessed on $19^{\text {th }}$ December, 2007 at: http://www. swissinvestforum.ch/ content/eng/ program \%20(2007)/ wspitteler.html

Tawfiq, N.K., Anderson, L.A., Roberts, M. F., Phillipson, J.D., Bray, D.H. \& Warhurst, D.C. (2004) Antiplasmodial activity of Artemisa annua plant cell cultures. Plant Cell Reports 8, 425-428.

Vongtau, H.O., Abbah, J., Mosugu, O., Chindo, B.A., Ngazal, I.E., Salawu, A.O., Kwanashie, H.O. \& Gamaniel, K.S. (2004) Antinociceptive profile of the methanolic extract of Neorautanenia mitis root in rats and mice. Journal of Ethnopharmacology, 92, 317-324.

Vongtau, H.O., Amos, S., Binda, L., Kapu, S.D., Gamaniel, K.S., Kunle, O.F. \& Wambebe C. (2000) Pharmacological effects of the aqueous extract of Neorautanenia mitis in rodents. Journal of Ethnopharmacology, 72, 207-214.

Wafo, P., Nyasse, B., Fontaine, C. \& Sondengam, B.L. (1999) Aporphine alkaloids from Enantia chlorantha. Fitoterapia 70, 157160.

WHO (2002) The World Health Report 2002: Reducing Risks, Promoting Healthy Life. World Health Organization, Geneva. 